MEHMET AKIF ERSOY ÜNIVERSITESI
SAĞLIK BİLIMLERİ ENSTITÜSÜ DERGİI
"MAKÜ Sag. Bil. Enst. Derg."
http://edergi.mehmetakif.edu.tr/index.php/sabed/index

\title{
Filamentöz faj üzerinde eksperese edilen Hepatit B yüzey antijenine karşı antikor yanıtı
}

\author{
Antibody Response to Hepatitis B Surface Antigen Displayed on Filamentous \\ Phage
}

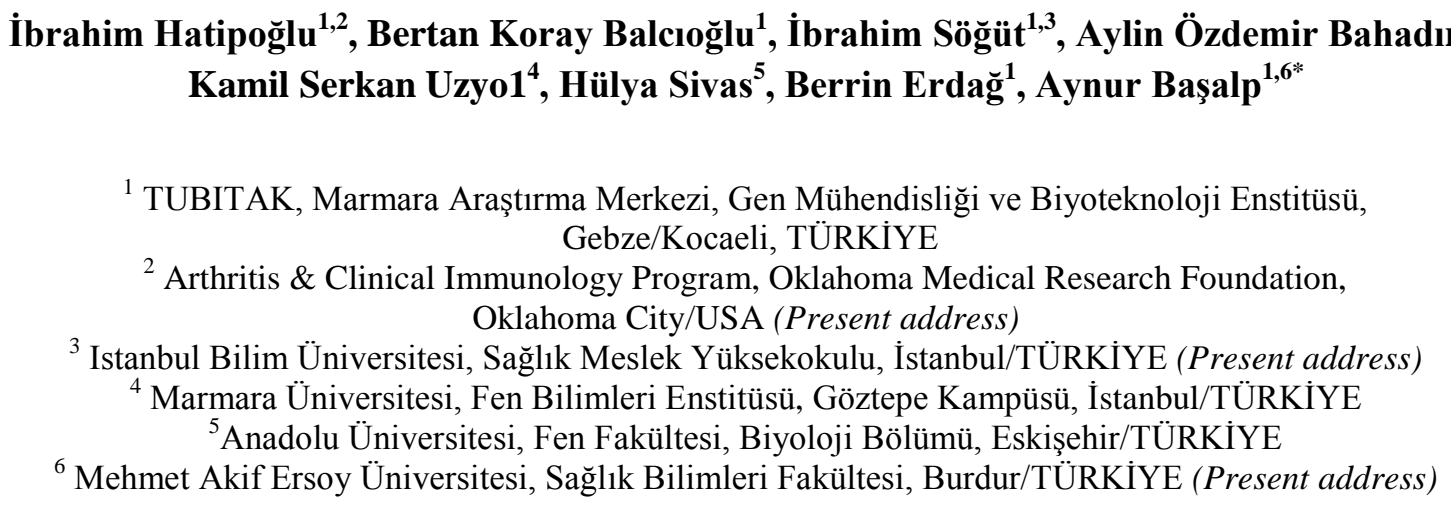

\begin{abstract}
Phages are highly immunogenic molecules capable of inducing both humoral and cellular immune response and have been used as potential vaccine delivery vehicles. In this study, the full-length Hepatitis B surface antigen (HBsAg) was expressed as HBsAg-pIII fusion protein on M13 phage and the efficacy of recombinant phage was studied in BALB/cJ mice. It was shown that the immunization of mice with the highest dose of recombinant phage $\left(10^{12}\right)$ generated an increased antibody response compared to wild-type phage immunization. After having a promising result in $\mathrm{BALB} / \mathrm{cJ}$ mice, recombinant phage was tested in Hepatitis B virus (HBV) transgenic mice and hybrid mice (C57BL/6JXBALB/c) and its effect was also compared with the well-known adjuvants such as alum and mineral oil adjuvants. Our results have shown that immunization of $\mathrm{BALB} / \mathrm{cJ}$ mice, HBV transgenic mice and hybrid mice with recombinant phage elicited an antigen-specific antibody response. The results also indicated that very strong adjuvants/carriers should be used to induce immune response in HBV carriers.
\end{abstract}

Key words: Adjuvant, Antibody response, Hepatitis B Virus, Phage display

Yazışma Adresi: Prof..Dr Aynur BAŞALP Mehmet Akif Ersoy Üniversitesi

Sağlık Bilimleri Fakültesi İstiklal Kampüsü, Burdur - TÜRKIYE

E-posta: abasalp@mehmetakif.edu.tr

Tel: +902482133500

Kaynak göstermek için: Hatipoğlu İ, Balcığlu B.K, Söğüt İ, Bahadir A.Ö, Uzyol K.S, Sivas H, Erdağ B, Başalp A. 2017.

Filamentöz faj üzerinde eksperese edilen Hepatit B yüzey antijenine karşı antikor yanıtı. MAKÜ Sag. Bil. Enst. Derg. 5(2): 124-134.

\begin{abstract}
Öz: Fajlar organizmada humoral ve hücresel immün yanıtı uyandırabilen yüksek immünojenik özelliğe sahip moleküllerdir ve potansiyel aşı taşıyıcısı olarak kullanılmaktadırlar. $\mathrm{Bu}$ çalışmada Hepatit B yüzey antijeni (HBsAg) tam molekül olarak M13 faj yüzeyinde füzyon protein olarak ekprese edildi ve rekombinant fajın antijenik etkisi BALB/cJ farelerinde incelendi. Farelerin yüksek dozda $\left(10^{12}\right)$ rekombinant faj ile immünize edilmesinin normal faja kıyasla daha yüksek antikor yanıtına neden olduğu gösterildi. BALB/cJ farelerinde elde edilen olumlu yanıt sonrası rekombinant fajın etkinliği Hepatit $\mathrm{B}$ virüsü (HBV) transgenik farelerde ve hibrid farelerde (C57BL/6JXBALB/c) incelendi ve ayrıca etkisi alüminyum adjuvantı ve mineral yağ adjuvantı gibi yaygın kullanımı olan adjuvantlarla karşılaştırıldı. Çalışmanın sonuçları BALB/cJ farelerin, HBV transgenik farelerin ve hibrid farelerin rekombinant faj ile immünizasyonunun antijene özgü antikor yanıtı oluşturduğunu gösterdi. Sonuçlar HBV taşıyıcılarında immün yanıt oluşturmak için güçlü adjuvantların kullanılması gerektiğini işaret etmektedir.
\end{abstract}

Anahtar sözcükler: Adjuvant, Antikor yanıtı, Hepatit B virüsü, Faj gösterim

Geliş Tarihi: 21.06.2017～Kabul Tarihi: 27.11.2017 


\section{Introduction}

Adjuvants are used to elicit high and long-lasting immune response to antigens and with the use of adjuvants in vaccine formulation, humoral and cellular immunity can be selectively modulated (Coffman et al., 2010; Lambrech et al., 2009; Mastelic et al, 2013). The advent of molecular biology made it possible to replace whole inactivated microorganisms with the recombinant products which are poor immunogens and strictly requires adjuvants to evoke the immune response. Aluminum compounds are still the most commonly used adjuvants in human vaccines (Gregorio et al., 2008; Lindblad, 2004). Hepatitis B virus (HBV) vaccine, the first successful vaccine manufactured in yeast and mammalian cells with genetic engineering technology, is prepared with aluminum hydroxide and effective in healthy people after three immunizations. However, in some subjects, the antibody titer may decrease in the course of 6 months following third immunization and also HBV carriers, immunocompromised adults and patients with organ transplant and chronic renal failure do not respond well to the current vaccine. Both the cellular and humoral immune responses are needed to recover from acute hepatitis B infection (Bantvala et al., 2001; Bertoletti and Gehring, 2006; Zanetti et al., 2008). Aluminum compounds, in general, are relatively weak adjuvant particularly in the induction of cellular immune response and mostly stimulate humoral immunity (Flach et al., 2011; Marrack et al., 2009). Thus, there is a need for better vaccine adjuvants in order to stimulate both cellular and humoral immune response and capable of mediating viral clearance in chronic hepatitis B infection.

In order to induce strong immune response to HBV vaccine in all subjects, several adjuvants have been tested (Ambrosch et al., 2000; Cooper et al., 1991; Mc Cluskie and Davis,1998; Nellore et al., 1992; Pichichero, 2008; Traquina et al., 1996) and one of the latest alternatives is the use of phage particles as carrier. Since it was first reported by Smith (1985), recombinant phages have been used as potential vaccine delivery vehicles. Phages are highly stable, resistant to many stresses, cannot replicate in the eukaryotic host and easy to manage. They are also highly immunogenic and naturally immunostimulatory molecules capable of inducing both humoral and cellular immunity. The antigens presented on the phage surfaces become ready conjugates and do not require the presence of any other adjuvants (Gao et al., 2010; Molenaar et al., 2002). The use of genetically engineered phages expressing different peptides on their surface has been reported in several studies (Bahadir et al., 2011; Bastien et 
al., 1997; Solomon, 2007; Van Houten et al., 2006) and one of the most widely used display systems is M13 filamentous phages.

In the current study, Hepatitis B virus surface antigen (HBsAg), as a full-length protein, was genetically inserted into M13 phage coat protein III, due to the convenience of pIII protein for the expression of large proteins. BALB/cJ mice were then immunized with the various amounts of recombinant phages and its potential use to induce $\mathrm{HBsAg}$ specific antibody response was investigated. Therapeutic effect of recombinant phages was tested in HBV transgenic mice and hybrid mice and influence on immune response was also compared with the well-known adjuvants such as alum and mineral oil adjuvants.

\section{Materials and Methods}

\section{Construction of phage displaying HBsAg}

HBsAg gene was amplified by PCR using a plasmid containing the whole HBV genome (ATCC, pAM6, USA) as a template and primers, designed from the SDCD Biology Workbench Internet website, including Sfi I and Not I restriction enzymes digestion sites (http://workbench.sdsc.edu). The amplified gene was then cloned into pCANTAB5E phagemid vector and transformed into Escherichia coli (E.coli) TG1 bacteria (Pharmacia, The Netherlands) with calcium chloride transformation. Clones were controlled by colony PCR for the insertion of HBsAg gene into the vector (Güssow and Clackson, 1989). Positive clones were then infected with M13 helper phages (Pharmacia, The Netherlands) to obtain infective phages displaying HBsAg-pIII fusion protein on their surface. Phages were tested for their binding properties to anti-HBsAg polyclonal rabbit antibodies with phage ELISA assay. DNA sequence of positive clones was analysed with CEQ 8800 Sequence Analyser (Beckman Coulter, USA). Phages were amplified by M13K07 helper phage infection. After growth, phages were isolated by PEG $6000 / \mathrm{NaCl}$ precipitation and then filter sterilized with MillexHV (Millipore) filter. The sterilized phages were used for immunization of mice and ELISA.

\section{Phage ELISA}

ELISA plates were coated with anti-HBsAg polyclonal antibodies (1/200). After overnight incubation at $4^{\circ} \mathrm{C}$, the wells were washed with TPBS (PBS containing $0.1 \%$ Tween). Then, HBsAg displaying phages $\left(10^{10} \mathrm{pfu}\right)$ were added to wells and incubated for 
one hour at room temperature. After washing with TPBS, HRP-conjugated anti-M13 antibody (1/1000 dilution) (Amersham, Biosciences) and substrate were added subsequently and the results were read at $\mathrm{OD}_{405}$ with Bio-Rad Benchmark microplate reader.

\section{Immunization of mice}

Eight-week-old BALB/cJ, HBV transgenic mice (Bagis et al., 2006) and hybrid mice as control groups $(\mathrm{C} 57 \mathrm{BL} / 6 \mathrm{JXBALB} / \mathrm{c})$ were immunized three or four times with recombinant phage and wild type (WT) phages at three weeks intervals, intraperitoneally. The experimental groups were given $1 \times 10^{10}, 1 \times 10^{11}$ and $1 \times 10^{12}$ recombinant phages in $0.1 \mathrm{ml}$ PBS (pH:7.2) per mouse. Control groups were injected with the same amounts of wild type phage; Commercial Hepatitis B virus vaccine ( $2 \mu \mathrm{g} /$ mouse) (inactivated suspension of $\mathrm{HBsAg}$ containing pure $\mathrm{S}$ and pre $\mathrm{S}$ proteins produced from $\mathrm{CHO}$ cells and contains aluminum hydroxide as adjuvant) (GenHevac B Pasteur, France) and plasma purified HBsAg (2 $\mu \mathrm{g} /$ mouse) (Fitzgerald, USA) prepared in Freund's complete and incomplete adjuvants (FCA, IFA) (Sigma, USA). Four mice were used in each group and experiments repeated twice. The mice were bled through tail vein and antibody response was measured by ELISA.

All the animal experiments in this study were approved by the Ethics Committee of Genetic Engineering and Biotechnology Institute of TUBITAK Marmara Research Center.

\section{Detection of antibody response by ELISA}

Antibody response to HBsAg was measured by indirect ELISA. Microtiter ELISA plates were coated with $\mathrm{HBsAg}(400 \mathrm{ng} / \mathrm{ml})$ in PBS at $4^{\circ} \mathrm{C}$ by overnight incubation. After washing with PBS-Tween $20(0.5 \%)$ and blocking with $1 \%$ skimmed milk powder, the diluted mouse serum (1/50 or $1 / 100)$ was added to each well and incubated for $1 \mathrm{hr}$ at $37^{\circ} \mathrm{C}$. The wells were washed and bound antibody was detected with alkaline phosphatase conjugated goat anti-mouse polyvalent antibody (Sigma, at 1/1000 dilution) by incubating the plates at $37^{\circ} \mathrm{C}$ for additional $1 \mathrm{hr}$. Plates were then washed and para nitrophenyl phosphate (PNPP) at 1 $\mathrm{mg} / \mathrm{ml}$ in substrate buffer (0.1 M Glycine, $\mathrm{pH}: 10.4,1 \mathrm{mM} \mathrm{ZnCl}_{2}$ and $1 \mathrm{mM} \mathrm{MgCl}_{2}$ ) was added and the absorbance at $405 \mathrm{~nm}$ was measured by BioTec EIA reader (Bio-Rad 3550, USA). 


\section{Statistical analysis}

Differences between the groups were analyzed by one-way ANOVA (Tukey's test) using SPSS 17.0 computer program (IBM, USA). Values were considered to be statistically significant when $\mathrm{P}<0.01$.

\section{Results and Discussion}

It has been well shown that phage particles can be a promising approach to generate a strong immune response to various antigens including HBV (Bakhshinejad and Sadeghizadeh, 2014; Minenkova et al., 1993; Tan and Ho, 2014; Wan et al., 2001; Yang et al., 2005). One of the most frequently used display systems is M13 filamentous phage which permits the generation of peptides and antibody fragments (Sidhu, 2001). In this study, full-length Hepatitis B surface antigen (HBsAg) was expressed as HBsAg-pIII fusion protein on M13 phage. A DNA fragment of approximately 675 bp was amplified by PCR with HBsAg specific primers from the pAM6 plasmid. The PCR amplification products were controlled by agarose gel electrophoresis and approximately $675 \mathrm{bp}$ amplification product was monitored. The amplified band was extracted from the agarose gel, digested with Sfi I and Not I restriction enzymes, and the PCR template was then inserted into the pCANTAB5E phagemid vector. The recombinant vector was then transferred into E. coli TG1 cells by calcium chloride transformation. HBsAg gene insert sequence was amplified by colony PCR and sequenced using CEQ 8800. Recombinant $E$. coli TG1 bacteria were infected with M13 helper phages for the production of infective phage displaying HBsAg on their surface as HBsAg-pIII fusion protein. The binding property of phages displaying HBsAg was tested with phage-enzyme linked immunosorbent assay (phage-ELISA). As it is shown in Figure 1 that, anti-HBsAg polyclonal antibody was recognizing the HBsAg displayed on the phage surface.

To evaluate the immunogenicity of recombinant phage displaying $\mathrm{HBsAg}$ in naive mice, BALB/cJ mice were immunized three times, intraperitoneally, with $10^{10}, 10^{11}$ and $10^{12}$ recombinant phage particles. Control groups were given wild type phage only and the antibody responses in all groups were followed. Figure 2 shows that recombinant phage immunization at the highest dose $\left(10^{12} /\right.$ mouse) was able to induce HBsAg-specific antibody response in $\mathrm{BALB} / \mathrm{cJ}$ mice; however, there was no difference between the groups when the 
mice were immunized with $10^{10}$ and $10^{11}$ recombinant phage particles. This might be due to the presence of pIII protein on M13 phage surface as 5 copies.

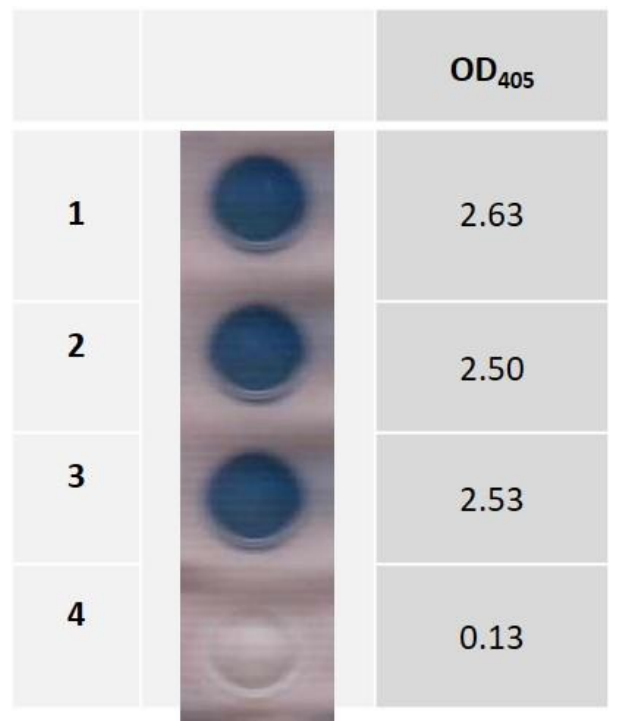

Figure 1. The picture and the absorbance values $\left(\mathrm{OD}_{405}\right)$ of phage ELISA results. Line 1 to 3 (triplicate) indicates the binding of HBsAg displaying phages to anti-HBsAg polyclonal antibody and line 4 is the negative control.

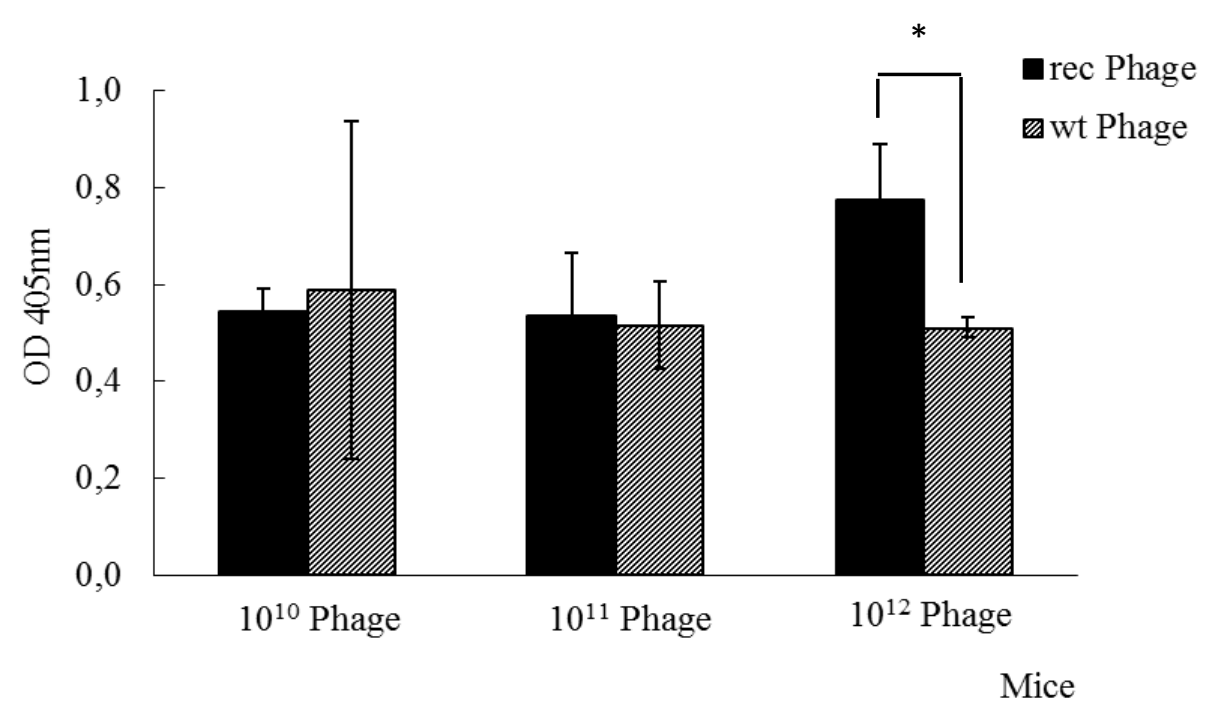

Figure 2. HBsAg-specific antibody response in BALB/cJ mice immunized with recombinant and wild type phage. Mice were immunized three times, intraperitonally and sera were tested for the detection of antigen specific antibody. $\mathbf{m}$ : recombinant phage (rec Phage); $\mathbf{a}$ : wild type phage (wt Phage). Data presented in the figure were means with standard error and $* \mathrm{P}<0.01$ was considered to be statistically significant. 
Although our initial results demonstrated that recombinant phage immunization could stimulate enhanced HBsAg specific antibody response in naive mice, its therapeutic effect was also tested in HBV transgenic mice to elicit the immune response in the presence of an antigen. HBV transgenic mice were then immunized with recombinant phage to examine if the recombinant phage vaccination could break immune tolerance in the presence of HBsAg and mediate the clearance of virus in HBV carriers. Transgenic mice were immunized with the $10^{12}$ recombinant phage and wild type phage and antibody response was detected. HBV transgenic mice were generated from hybrid mice CB6F1 (C57BL/6JXBALB/c). As control of HBV transgenic mice, all immunizations were repeated with hybrid mice. Efficacy of recombinant phage immunization was also compared with the well known adjuvants such as aluminum adjuvant and mineral oil adjuvants. Both transgenic mice and hybrid mice were immunized with commercial HBV vaccine prepared with alum adjuvant and plasma purified HBsAg emulsified in Freund's Complete and Incomplete adjuvant. In our previous studies, the optimal immunization dose of HBsAg in FCA was determined as $2 \mu \mathrm{g}$ antigen/mouse, hence, the same amount of antigen is used here.

Figure $3 \mathrm{~A}$ and $3 \mathrm{~B}$ show the antibody response in both transgenic and control group after third and fourth immunization, respectively. As it can be seen from the figures, the recombinant phage immunization generated a good antibody response in HBV transgenic mice as in hybrid mice and this response was higher in both groups compared to WT phage immunization. As it is well known that HBV carriers do not respond well to the alum adjuvanted vaccine and we also obtained the low level of antibody response in HBV transgenic mice. However, immunization of both transgenic mice and hybrid mice with purified HBsAg prepared with mineral oil adjuvant induced very high HBsAg-specific antibody response in both groups especially after fourth immunization. HBsAg level in sera of all groups were also tested with ELISA, but no decrease in antigen quantity could be obtained (data are not shown). This might be due to the high level expression of antigen in transgenic mice we used. Hong et al. (2011) have also shown that Lentivector immunization induced HBsAg specific immune response in transgenic mice expressing low level of antigen, but failed to break the tolerance in mice having high level of antigen. 


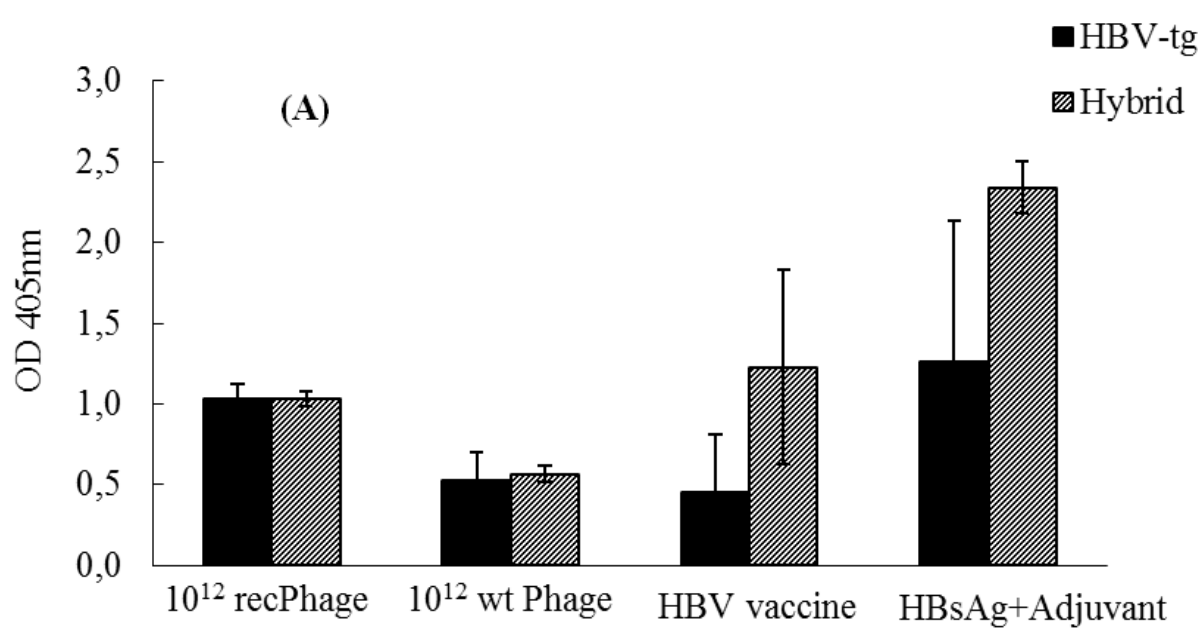

Mice

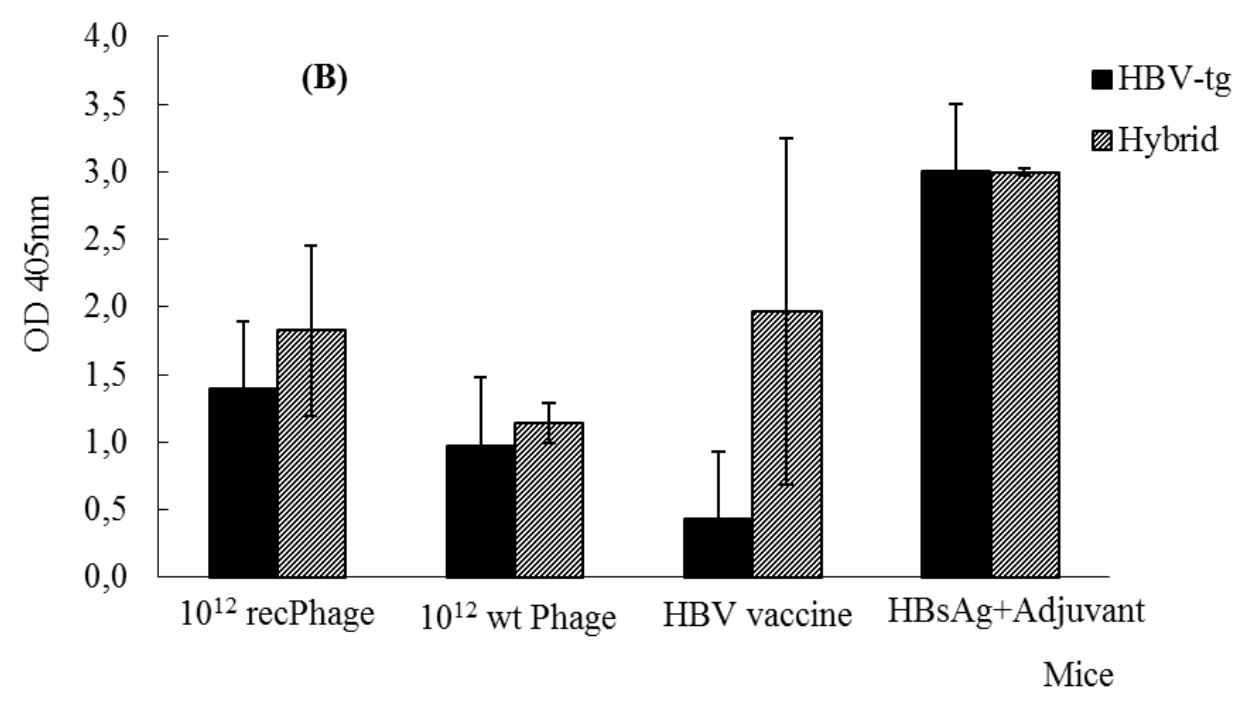

Figure 3. Comparison of the effect of recombinant and wild type phage immunization in HBV transgenic and hybrid mice with the well known adjuvants. Mice were immunized with four times with the $10^{12}$ recombinant and wild type phages. Control groups were also immunized with the commercial HBV vaccine (alum adjuvanted vaccine) and HBsAg prepared in FCA and IFA. Sera were tested for HBsAg specific antibody after third (A) and fourth immunization (B). a: HBV transgenic mice (HBV-tg); $\mathbf{a}$ : hybrid mice. Data presented in the figure were means with standard error of the mean. 
Innovative applications of phage display technology to develop a better HBV vaccine and the expression of HBsAg on the phage coat proteins have been shown by several groups. But, in their studies, HBsAg as an epitope or mimotope was displayed in the major coat protein pVIII because of its high copy number (2700 copy per phage). The sequences fused to pVIII are short (about 6-8 amino acid) due to the closeness of the abundant proteins on the phage surface (Meola et al., 1995; Wan et al., 2001). PIII protein of M13 phage is present at 5 copies per phage particle and hence, is convenient for the expression of a large protein. It also contributes to the structural stability of the phage and necessary for host cell recognition and infection. The preS domain of HBV was cloned into g3p protein of M13 bacteriophage by Kok et al. (2002), but the effect on immune response was not studied. Meola et al. (1995) have cloned HBsAg on to pIII protein, but it was a mimotope of the antigen. In another study, the major immunodominant region of HBsAg was fused to the capsid protein of $\mathrm{T} 7$ phage (Tan et al., 2005). However, in our study, HBsAg was displayed as a whole protein on pIII protein of M13 phage and its adjuvant effect was tested and compared with the well known adjuvants in HBV transgenic mice for the first time. An enhanced antibody response elicited by recombinant phage and mineral oil adjuvant in HBV transgenic mice suggest that very strong adjuvants/carriers should be used to induce immune response in HBV carriers and recombinant phages can be one of the promising alternatives.

\section{Conclusion}

In the present study, the full-length Hepatitis B surface antigen was expressed as HBsAg-pIII fusion protein on M13 phage and therapeutic efficacy was tested in HBV transgenic mice. Adjuvant effect of recombinant phage was also compared with aluminum and mineral oil adjuvant. The results have shown that the use of strong adjuvants may be a promising approach to induce a better immune response in HBV carriers.

\section{Acknowledgements}

This work was supported by a grant from TUBITAK KAMAG 1007 - $105 \mathrm{G} 056$ project. The authors wish to thank to Aydın Bahar, Şakir Sekmen and Erman Ateş for their excellent technical assistance. 


\section{References}

1. Ambrosch F, Wiedermann G, Kundi M, et al. 2000. A hepatitis B vaccine formulated with a novel adjuvant system. Vaccine. 18: 20952101.

2. Bagis H, Arat S, Odaman HM et al. 2006. Stable transmission and expression of the Hepatitis B Virus total genome in hybrid transgenic mice until F10 generation. J. Exp. Zool. 305a: 420-427.

3. Bahadir AO, Balcioglu BK, Uzyol KS, et al. 2011. Phage displayed HBV core antigen with immunogenic activity. Appl. Biochem. Biotech.165:1437-1447.

4. Bakhshinejad B, Sadeghizadeh M. 2014. Bacteriophages and their applications in the diagnosis and treatment of hepatitis B virus infection. World J. Gastroenterol. 20(33): 11671-11683.

5. Bantvala J, Van Damme P, Oehen S. 2001. Lifelong protection against hepatitis $\mathrm{B}$ : the role of vaccine immunogenicity in immune memory. Vaccine. 19: 877- 885.

6. Bastien N, Trudel M, Simard C. 1997. Protective Immune responses induced by the immunization of mice with a recombinant bacteriophage displaying an epitope of the Human Respiratory Syncytial Virus. Virology. 234: 118-122.

7. Bertoletti A, Gehring AJ. 2006. The immune response during hepatitis B virus infection. J. Gen. Virol. 87: 1439-1449.

8. Coffman RL, Sher A, Seder RA. 2010. Vaccine adjuvants: Putting innate immunity to work. Immunity. 33: 492-503.

9. Cooper PD, Turner R, McGovern J. 1991. Algammulin (gamma inulin/alum hybrid adjuvants) has a greater adjuvanticity than alum for hepatitis B surface antigens in mice. Immunol. Lett. 27: 131-134.

10. Flach TL, Gilbert N, Hari A, et al. 2011. Alum interaction with dendritic cell membrane lipids is essential for its adjuvanticity. Nat. Med. 17: 479-487.
11. Gao J, Wang Y, Liu Z, et al. 2010. Phage display and its application in vaccine design. Ann. Microbiol. 60: 13-19.

12. Gregorio E, Tritto E, Rappuoli R. 2008. Alum adjuvanticity: Unrevealing a century old mistery. Eur. J. Immunol. 38: 2068-2071.

13. Güssow D, Clackson T. 1989. Direct clone characterization from plaques and colonies by the polymerase chain reaction. Nucleic Acid Res. 17: 4000.

14. Hong Y, Peng Y, Michael M, et al. 2011. Lentivector expressing $\mathrm{HBsAg}$ and immunoglobulin $\mathrm{Fc}$ fusion antigen induces potent immune responses and results in seroconversion in $\mathrm{HBsAg}$ transgenic mice. Vaccine. 29: 3909-3916.

15. Kok WL, Yusoff $K$, Nathan $S$, et al. 2002.Cloning, expression and display of the preS domain of hepatitis $B$ virus on filamentous bacteriophage M13. J. Biochem. Mol. Biol. Biophys. 6: 55-58.

16. Lambrecht BN, Kool M, Willart MAM, et al. 2009. Mechanism of action of clinically approved adjuvants. Curr. Opin. Immunol. 21: 23-29.

17. Lindblad EB. 2004. Aluminum adjuvants in retrospect and prospect. Vaccine. 22: 36583668.

18. Marrack P, McKee AS, Munks MW. 2009. Towards an understanding of the adjuvant action of aluminum. Nat. Rev. Immunol. 9: 287-293.

19. Mastelic B, Garçon N, Guidice GD, et al. 2013. Predictive markers of safety and immunogenicity of adjuvanted vaccines. Biologicals. 41: 458-468.

20. Mc Cluskie MJ, Davis HL. 1998. CpG DNA is a potent enhancer of systemic and mucosal immune responses against hepatitis B surface antigen with intranasal administration to mice. Immunology. 161: 4463-4466. 
21. Meola A, Delmastro P, Monaci P, et al. 1995. Derivation of vaccines from mimotopes: Immunologic properties of human Hepatitis B Virus surface antigen mimotopes displayed on filamentous phage. J. Immunol. 154: 31623172 .

22. Minenkova OO, Ilyichev AA, Kishchenko GP, et al. 1993. Design of specific immunogens using filamentous phage as the carrier. Gene. 128: $85-88$

23. Molenaar TJM, Michon I, Haas SAM, et al. 2002. Uptake and processing of modified bacteriophage M13 in mice: implications for phage display. Virology. 293: 182-191.

24. Nellore RV, Pande PG, Young D et al. 1992. Evaluation of biodegradable microspheres as vaccine adjuvant for hepatitis B surface antigen. J. Parent. Sci. Techn. 46: 176-180.

25. Pichichero ME. 2008. Improving vaccine delivery using novel adjuvant systems. Hum. Vaccines. 44: 262-270.

26. Sidhu SS. 2001. Engineering M13 for phage display. Biomol. Eng. 18: 57-63.

27. Smith GP. 1985. Filamantous fusion phage: Novel expression vectors that display cloned antigens on the virion surface. Science. 228: $1315-1317$.

28. Solomon B. 2007. Active immunization against alzheimer's $\beta$-amyloid peptide using phage display technology. Vaccine. 25: 30533056 .

29. Tan GH, Yusoff $\mathrm{K}$, Seow $\mathrm{HF}$, et al. 2005.Antigenicity and immunogenicity of the immunodominant region of Hepatitis B surface antigen displayed on bacteriophage T7. J. Med. Virol. 77: 475-480.
30. Tan WS, Ho KL. 2014. Phage display creates innovative applications to combat hepatitis B virüs. World J. Gastroenterol. 20(33): 1165011670.

31. Traquina $\mathrm{P}$, Morandi $\mathrm{M}$, Contorni $\mathrm{M}$, et al. 1996. MF59 Adjuvant enhances the antibody response to recombinant hepatitis $\mathrm{B}$ surface antigen vaccine in primates. J. Infect. Dis. 174: $1168-1175$

32. Van Houten NE, Zwick MB, Menendez A, et al. 2006. Filamentous phage as an immunogenic carrier to elicit focused antibody responses against a synthetic peptide. Vaccine. 24: 4188-4200

33. Wan $\mathrm{Y}, \mathrm{Wu} \mathrm{Y}$, Bian J, et al. 2001. Induction of hepatitis $\mathrm{B}$ virus-specific cytotoxic $\mathrm{T}$ lymphocytes response in vivo by filamentous phage display vaccine. Vaccine. 19: 29182923.

34. Yang Q, Wang L, Lu D, et al. 2005. Prophylactic vaccination with phage-displayed epitope of C. albicans elicits protective immune responses against systemic candidiasis in C57BL/6 mice. Vaccine. 23: 4088-4096.

35. Zanetti AR, Van Damme $P$, Shouval D. 2008. The global impact of vaccination against hepatitis B: A historical overview. Vaccine. 26: 6266-6273 